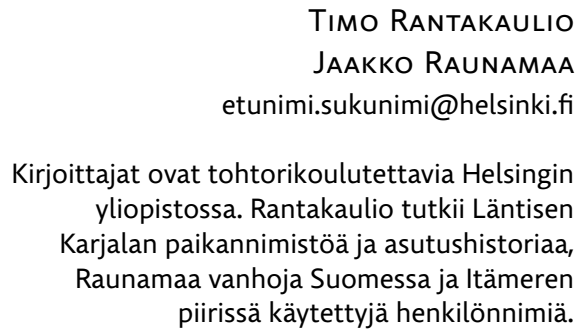

\title{
Substantiivien moniulotteisista merkityksistä
}

Zhengdao Ye (toim.): The semantics of nouns. Oxford: Oxford University Press 2017. 315 s. ISBN 978-0-19-873672-1.

"En voi istua vieressäsi", sanoi eräs rouva minulle kahvitellessamme Tukholman suomalaisella kirkolla reilu vuosi sitten. "Olin ajatellut jutella jonkun kanssa, mutta sinua en tunne." Sen jälkeen hän vaihtoi paikkaa. - Esimerkiksi tämä tapaus muistui mieleeni lukiessani Zhengdao Yen toimittamaa teosta substantiivien merkityksestä. Siinä kerrotaan muun muassa kiinan kielen sanoista, joita käytetään tutuista ja vieraista ihmisistä. Teoksessa käsitellään substantiivien merkityksiä niin sanotun alkusanakielen (Natural Semantic Metalanguage) avulla, jonka Anna Wierzbicka (1996) ja hänen seuraajansa ovat kehittäneet. Alkusanakielen idea on identifioida rajallinen määrä käsitteitä, joille löytyy sana kaikista maailman kielistä ja joiden avulla kaikki

\section{Lähteet}

KePsu, Saulo 1981: Pohjois-Kymenlaakson Kylännimet. Helsinki: Suomalaisen Kirjallisuuden Seura.

- 2005: Uuteen maahan. Helsingin ja Vantaan vanha asutus ja nimistö.Helsinki: Suomalaisen Kirjallisuuden Seura.

Lehikoinen, LAILA 1988: Kirvun talonnimet. Karjalaisen talonnimisysteemin kuvaus. Helsinki: Suomalaisen Kirjallisuuden Seura.

Nissilä, Viljo 1975: Suomen Karjalan Nimistö. Joensuu: Karjalaisen kulttuurin edistämissäätiö. muut kaikkien kielten käsitteet ja sanat voidaan selittää. Kirja on kiinnostavaa ja hyödyllistä luettavaa myös sellaisille, jotka eivät tutkimuksessaan käytä juuri kyseistä metodia. ${ }^{1}$ Sen toimittaja työskentelee kiinan kielen ja kirjallisuuden lehtorina Australian kansallisyliopistossa (Australian National University) ja on julkaissut monia artikkeleita, joissa hän käyttää metodinaan alkusanakieltä.

Johdantoluvussa Ye asettaa kirjalle kaksi päätavoitetta. Tarkoitus on yhtäältä valaista substantiivien merkityksiä eri kielissä, toisaalta mallintaa eri domeeneihin kuuluvia substantiiveja. Toisin sanoen ajatuksena on, että erityyppisiin asioihin viittaavia substantiiveja

1. Ajantasaista ja kattavaa tietoa alkusanakielestä on tarjolla sivustolla https://intranet. secure.griffith.edu.au/schools-departments/ natural-semantic-metalanguage. Ks. suomenkielinen yleisesittely Vanhatalo \& Tissari 2017. 
tulisi kuvata eri tavoin siten, että kullekin substantiivijoukolle luodaan omanlaisensa selitysmalli. Teoksen luvuissa käsitellään substantiiveja, jotka ilmaisevat muun muassa perhe- ja sukulaisuussuhteita, toisiinsa komplementaarisessa suhteessa olevia käsitteitä, hengellisiä tai mielikuvitusolentoja, persoonallisuuden piirteitä ja kehon osia. Lukuja on yhteensä kymmenen, ja niissä käsitellään neljäätoista eri kieltä.

\section{Enkeleitä, äitejä ja mehiläisiä}

Johdantoa seuraa Wierzbickan laatima luku sukulaissuhteita nimeävistä substantiiveista ("The meaning of kinship terms: A developmental and cross-linguistic perspective"). Luvussa kuvaillaan ennen kaikkea äitiä, isoäitiä ja tätiä merkitseviä sanoja englannin kielessä. Vaikka mukana on vertailuja muihin kieliin sekä englannin eri varieteettien välistä vertailua, erityisesti tarkastellaan sitä, miten lapsi oppii käyttämään kyseisiä sanoja ja miten lapsen käyttämien sanojen merkitykset eroavat aikuisten käyttämistä. Keskeinen ajatus on, että lapsenkielen sanojen merkitykset muuttuvat kognition kehittyessä. Niinpä esimerkiksi sana mummy tarkoittaa taaperolle eri asiaa kuin teini-ikäiselle, koska pieni lapsi ei vielä ymmärrä, että jokaisella ihmisellä on äiti, vaan keskittyy ajattelussaan omaan äitisuhteeseensa.

Suomalaisella kirkolla kuulemani kommentti tuli mieleeni Yen omasta luvusta "The semantics of social relation nouns in Chinese", jossa kerrotaan mandariinikiinan sanapareista shēngrén-shúrén ja zijìrén-wàirén. Niillä ilmaistaan toisaalta viitatun henkilön tuttuutta tai vierautta puhujalle, toisaalta sosiaaliseen yhteisöön kuulumista tai sen ulkopuolella olemista. Henkilö ei kummassakaan tapauksessa voi olla yhtä aikaa molempia vaan kuuluu aina jompaankumpaan ryhmään. Hän voi kuitenkin olla puhujalle tuttu kuulumatta tämän sosiaaliseen yhteisöön. Hän voi myös ajan mittaan vaihtaa jäsenyttään ryhmästä toiseen.

Sandy Habibin luvussa "The meanings of 'angel' in English, Arabic and Hebrew" vertaillaan enkeliä tarkoittavia sanoja englannin, arabian ja heprean kielissä. Habib lähtee ajatuksesta, että kristinuskolla, islamilla ja juutalaisuudella on paljon yhteisiä piirteitä mutta että ne kuitenkin myös eroavat toisistaan. Hänen mukaansa enkelit ovat tärkeitä kaikissa näissä uskonnoissa, joten kyseessä on keskeinen käsite, jota kannattaa tutkia. Siksi hän analysoi enkeliä tarkoittavien sanojen käyttöä korpuksissa. Olennaisiksi kysymyksiksi nousevat muun muassa seuraavat: onko enkeleitä oikeasti olemassa, missä heitä on, miltä he näyttävät ja tekevätkö he ihmisille hyvää vai pahaa? Habibin mukaan käsitykset näistä asioista vaihtelevat jonkin verran kielestä toiseen. Hänen laatiessaan enkelin määritelmiä eri kielille nousee aineiston pohjalta esille muun muassa se ero, että englanninkielisissä korpuksissa enkeleitä kuvataan hyviksi olennoiksi, jotka tekevät ihmisille hyvää, mutta arabiankielisessä aineistossa enkelit tekevät ihmisille myös pahaa.

Uskontoon liittyviä asioita sivutaan myös Carsten Levisenin luvussa "Personhood constructs in language and thought: New evidence from Danish", joka käsittelee tanskan kielen substantiiveja sind ja ånd. Levisen toteaa, ettei näitä sanoja nykyään useinkaan käytetä niiden alkuperäisissä kristillisissä merkityksissä. Ennen kaikkea hän korostaa, ettei näille sanoille löydy tarkkoja merkitysvastineita edes tanskalle läheistä sukua olevista kielistä. Leviseniä mukaillen olisi siis väärin ajatella, että sanan sind voisi yksinkertaisesti kääntää suomen kielen sanalla sielu tai mieli tai ånd-sanan suomen kielen sanalla henki. Luvun sanoma on toisin sanoen kahtalainen. Ensinnäkin kauan käytössä olleiden sanojen nykymerkityksiä määriteltäessä tulee keskittyä siihen, miten ihmiset nykyään sanoja käyttävät, eikä sii- 
hen, mitä tiedetään niiden historiasta. Toiseksi tulee välttää sitä harhakäsitystä, että kahden maantieteellisesti toisiaan lähelle sijoittuvan kielen sanat olisivat helposti käännettävissä yhdestä kielestä toiseen. Alkusanakieli auttaa ymmärtämään nyansseja, kuten sitä, että sind-sanalla ei tanskassa viitata vain yksittäisen henkilön mieleen vaan myös sen samankaltaisuuteen muiden mielien kanssa tietyn ryhmän sisällä.

Mielestä siirrytään kehoon Carol Priestleyn luvussa "Some key body parts and polysemy: A case study from Koromu (Kesawai)", jossa käsitellään koromun kielen kättä ja jalkaa tarkoittavia sanoja. Kirjoittajan tarkoituksena on havainnollistaa, miten alkusanakielen avulla voidaan yleisemminkin kuvata kehon osia tarkoittavia sanoja. Tässä nimenomaisessa Australian aboriginaalien kielessä sanat wapi 'käsi' ja ehi 'jalka' toimivat samaan tapaan kuin suomen kielessä ja toisin kuin englannin ja ruotsin kielissä. Koromun puhujilla ei siis ole tapana käyttää eri sanaa käsivarresta (engl. arm) ja kädestä ranteesta alaspäin (engl. hand) tai jalasta (engl. leg) ja jalkaterästä (engl. foot). Olennaista alkusanakielen teorian kannalta on rajanveto sen välillä, mikä kehon eri osien hahmottamisessa on eri kielille yhteistä ja millaisia eroavaisuudet voivat olla.

Australian aboriginaalikielissä pysytellään myös seuraavassa luvussa "The semantics of standing-water places in English, French, and Pitjantjara/Yankunytjatjara”, jossa Helen Bromhead selvittää, millaisia vastineita englannin sanoilla lake ja pond on ranskassa ja pitjantjarassa ja yankunytjatjarassa. Selviää, etteivät edes ranskan järveä ja lampea tarkoittavat sanat vastaa englannin kielen sanoja, pitjantjaran sanoista puhumattakaan. Luvussa selitetään, miten sanastolliset erot liittyvät kielten historiaan ja maantieteellisiin eroihin, kuten siihen, että pitjantjaran puhujat etsivät vettä erämaassa esi- merkiksi kiven koloista. Nimenomaan veden peittämän alueen koolla on tässä suhteessa tärkeä merkitys, koska erämaassa elävälle pienikin vedensaantipaikka saattaa olla elintärkeä. Toisaalta ihmiset ovat eri maissa rakentaneet erikokoisia ja -mallisia vesialtaita, eivätkä englannin sanat lake ja pond tästä syystä suhtaudu toisiinsa täsmälleen samoin kuin ranskan lac ja étang.

Michael Roberts on luvussaan "The semantics of demonyms in English: Germans, Queenslanders, and Londoners" kiinnostunut siitä, miten alkusanakielellä voisi kuvata substantiiveja, jotka kertovat, että henkilö on kotoisin tietystä paikasta. Hän käsittelee sellaisia englannin kielen sanoja kuin Asian, German, Londoner ja Queenslander. ${ }^{2}$ Robertsin mukaan näiden substantiivien merkityksen kuvaamisessa pulmia tuottaa muun muassa se, miten ilmaista mahdollisuutta, että henkilö asuu tietyssä paikassa mutta ei katso olevansa sieltä kotoisin. Hän ehdottaa myös, että kuvauksen tulisi huomioida se, minkä kokoisesta ja tyyppisestä paikasta on kysymys. Ei ole samantekevää, onko kyse kaupungista vai maanosasta.

Ihmisistä siirrytään eläimiin Aung Sin kirjoittamassa luvussa "The semantics of honeybee terms in Solega (Dravidian)", jonka aiheena ovat mehiläistä tarkoittavat sanat Intiassa puhuttavassa solegan kielessä. Hänen tavoitteenaan on kuvata sellaisia sanoja, joita käyttävät mehiläisistä paljon tietävät alkuperäiskansan jäsenet eivätkä tieteellisen tutkinnon suorittaneet asiantuntijat. Tavalliset solegan kielen puhujat tuntevat mehiläiset hyvin, koska hunaja on heidän kotiseudullaan tärkeä tulonlähde. Luvussa esitettävät valokuvat neljän mehiläislajin edustajista eivät länsimaalaisen lukijan silmään juuri erotu toisistaan, mutta solegan kielen puhujat ym-

2. Näillä sanoilla on toki myös adjektiivista käyttöä, mutta Roberts tarkastelee niitä teoksen teeman mukaisesti substantiiveina. 
märtävät kuitenkin paitsi erot mehiläisten ulkonäössä myös niiden käyttäytymisessä. Heidän tietonsa koskevat esimerkiksi sitä, millaisista paikoista tietyn mehiläislajin edustajia voi löytää. Tämä on tärkeä tieto erotettaessa ja nimettäessä eri mehiläislajeja. Tästä syystä Si on sisällyttänyt sellaista tietoa mehiläislajien määritelmiin tätä teosta varten.

Teoksen viimeinen luku "Furniture, vegetables, weapons: Functional collective superordinates in the English lexicon" on muita teoreettisempi. Siinä Cliff Goddard pohtii substantiiveja, jotka nimeävät erilaisia funktionaalisia yläkategorioita. Hän kritisoi aikaisempaa sanastollisiin taksonomioihin liittyvää tutkimusta siitä, ettei siinä ole tehty riittävän hienovaraisia analyyseja eikä eroteltu ala- ja yläkategorioita parhaalla mahdollisella tavalla. Goddardin lähtöajatus on, että kaikki taksonomiset yläkäsitteet eivät teoreettisesta näkökulmasta katsottuna vastaa toisiaan. Esimerkiksi kaikki lintulajit voidaan ymmärtää sen pohjalta, millainen lintu on, mutta samaa on vaikea soveltaa huonekaluihin. Toisin sanoen on helpompaa määritellä lintu ja sen pohjalta lintulajit kuin määritellä huonekalu ja sen pohjalta pöytä, tuoli ja niin edelleen. Goddardin oma analyysi keskittyy jälkimmäisen tyyppisiin yläkäsitteisiin ja erityisesti kolmenlaisiin englannin kielen substantiiveihin: yhtäältä niihin, jotka esiintyvät vain yksikössä (esim. furniture), toisaalta niihin, jotka esiintyvät vain monikossa (esim. cosmetics) ja kolmanneksi ihmisen tekemiin artefakteihin, jotka ovat laskettavissa. Näitä viimeisimpiä edustavat muun muassa substantiivit weapon(s) ja vehicle(s).

Kaikki viitteet löytyvät kirjan lopusta. Niitä seuraa asiasana- ja henkilönnimihakemisto. Lisäksi omassa hakemistossaan on mainittu kaikki ne substantiivit, joiden merkitykset kirjassa on selitetty. On helppo nähdä, että vaikka kirjassa käsitellään useita eri kieliä, eniten käsitellään englannin kielen sanoja.

\section{Pohdinta}

Kirja antaa käsityksen siitä, millaisiin asioihin alkusanakielen kehittämisessä parasta aikaa keskitytään. Siinä puhutaan paljon niin kutsutuista upotuksista, joita alun perin käytettiin alkusanojen sijaan tilan säästämiseksi. Alkusanakieltä käyttävät tutkijat nimittäin huomasivat jossakin vaiheessa, että kun alkusanoja monimutkaisempia sanoja selitetään pelkillä alkusanoilla, selityksistä voi tulla epäkäytännöllisen pitkiä. Toisaalta pitkät selitykset on mahdollista jakaa lyhyempiin osiin, jotka toistuvat monien sanojen määritelmissä. Päätettiin, että tällaiset osat voitaisiin määritellä kerran ja sitten viitata jo määriteltyyn asiaan sen sijaan, että asian selittämiseen käytettäisiin joka kerta monta riviä. Nyt vaikuttaa siltä, että upotusten käyttö on hyväksytty siinä määrin, että alkusanojen etsimisen sijaan keskitytään sellaisten upotusten määrittelemiseen, joiden avulla voidaan selittää mahdollisimman monia muita sanoja. Näiden lisäksi Goddard esittelee termin derivational base (s. 269), jota ei ole vielä käännetty suomeksi. Kyseessä on kuitenkin tuttu ilmiö, mahdollisuus johtaa yhdestä sanasta uusia sanoja.

Kirjaa lukiessa jääkin miettimään sitä, missä määrin alkusanakielellä operoivat tutkijat nostavat esille aikaisemmin havaitsematta tai varjoon jääneitä asioita ja missä määrin he antavat vanhoille ilmiöille uusia nimityksiä. Tähän lienee tässä yhteydessä mahdoton vastata tyhjentävästi, mutta itselleni nousi mieleen esimerkiksi ensyklopedisen merkityksen käsite, jota usein hyödynnetään kognitiivisessa lingvistiikassa. Ajatuksena on, että tiedämme sanojen merkityksistä paljon enemmän kuin sanakirjat antavat ymmärtää. On selvää, että näiden lukujen kirjoittajat ottavat ensyklopedisen merkityksen huomioon, vaikka he aina pyrkivätkin mahdollisimman tiiviisiin ja tyhjentäviin sananselityksiin. Tämä käy hyvin esiin 
Bromheadin luvusta, jossa lampien nimityksiä käsitellään muun muassa suhteessa puutarhojen rakentamisen historiaan. Ensyklopedisen tiedon läsnäolo teoksessa esitellyissä tutkimuksissa rikastuttaa lukuelämystä. Lukijalle avautuu mahdollisuus assosioida esille tulevia uusia asioita omiin kokemuksiinsa ihmisistä ja maailmasta. Hänelle avautuu myös tuoreita näkymiä siihen, miten yleisinhimillisiä ajattelun ja käyttäytymisen malleja sanoitetaan eri kulttuureissa ja millaiset seikat luovat eroja kielten välille.

Koko teoksen läpi kulkee ajatus siitä, että eri domeeneja edustavia substantiiveja pitäisi kuvata eri tavoin. Lukujen teemat on valittu sen mukaan, että jokainen niistä havainnollistaa, kuinka tiettyä joukkoa sanoja voidaan kuvata ikään kuin yhteismitallisesti. Tämä johtaa tärkeään yleisempään havaintoon, jota Ye käsittelee jo johdantoluvussaan: Vaikka monet kielentutkijat ovat keskittyneet verbien merkityksiin, substantiivit ovat yhtä lailla tärkeitä sanoja. Niiden merkitykset ovat hyvin rikkaita. Lisäksi substantiivien merkitysten avaaminen johtaa hedelmälliselle, tieteidenväliselle rajapinnalle. Kirja antaa tästä hyvän käsityksen, koska sen luvut sivuavat useita muita, toisistaan melko etäisiäkin tieteenaloja, kuten psykologiaa, teologiaa ja maantietoa.

Lukukokemusta häiritsevänä pidän sitä, että kirjoittajat käsittelevät lukujensa alussa kerrasta toiseen sitä, miten alkusanakieli toimii ja miksi sitä on hyödyllistä käyttää. Tämä tekee tietenkin mahdolliseksi sen, että kirjasta voi lukea vain yksittäisen luvun tai pari, vaikkei kyseistä teoreettista lähtökohtaa syvällisesti tuntisikaan. Toisaalta lukijaa auttaisi se, mikäli alkusanakielen aktiivikäyttäjien tämänhetkinen näkemys metodin käytöstä ja kehittämisestä olisi vielä koottu erilliseen lukuun. Viitteiden jättäminen kirjan loppuun helpottaa siirtymistä luvusta toiseen, mikäli kirjaa lukee kokonaisuutena.

Opetuskokemusteni pohjalta arvioin, että Yen toimittamasta teoksesta voisi hyvin valita luvun perusopiskelijoiden luettavaksi sanaston tai semantiikan kurssille. Sopivasti valittu luku kirvoittaisi opiskelijoilta varmasti keskustelua ja antoisia pohdintoja. Teoksen lukeminen ei ammattilaiselle ole vaivalloista. Voin lisäksi suositella teosta kaikille, jotka haluavat ymmärtää omaa ja toisen kieltä. Se avaa näkökulmia siihen, millaisia eroja on eri kielten saman tyyppisiä asioita ja ilmiöitä kuvaavien sanojen välillä ja kuinka paitsi eri kielten puhujat myös eri-ikäiset ihmiset hahmottavat sanoittamaansa maailmaa eri tavoin.

$$
\text { etunimi.sukunimi@english.su.se }
$$

Kirjoittaja työskentelee englannin kielen lehtorina Tukholman yliopistossa.

\section{Lähteet}

Vanhatalo, Ulla - Tissari, Heli 2017:

Esittelyssä alkusanakieli. - Virittäjä 121

s. 244-263. https://doi.org/10.23982/

vir.49707

Wierzbicka, Anna 1996: Semantics. Primes and universals. Oxford: Oxford University Press. 